\section{EMBRYARIDDLE \\ Aeronautical University}

SCHOLARLY COMMONS

\section{International Journal of Aviation,} Aeronautics, and Aerospace

\title{
Customer service 2.0: The Effect of Ryanair's Policy Change
}

John C. Griffith Ph.D.

Embry-Riddle Aeronautical University, griff2ec@erau.edu

Donna L. Roberts Ph.D.

WW/Applied Sciences, rober596@erau.edu

Follow this and additional works at: https://commons.erau.edu/ijaaa

Part of the Business Administration, Management, and Operations Commons, International Business Commons, Marketing Commons, and the Tourism and Travel Commons

\section{Scholarly Commons Citation}

Griffith, J. C., \& Roberts, D. L. (2021). Customer service 2.0: The Effect of Ryanair's Policy Change. International Journal of Aviation, Aeronautics, and Aerospace, 8(2). https://doi.org/10.15394/ ijaaa.2021.1577

This Article is brought to you for free and open access by the Journals at Scholarly Commons. It has been accepted for inclusion in International Journal of Aviation, Aeronautics, and Aerospace by an authorized administrator of Scholarly Commons. For more information, please contact commons@erau.edu. 
Customer service 2.0: The Effect of Ryanair's Policy Change

Cover Page Footnote

N/A

This article is available in International Journal of Aviation, Aeronautics, and Aerospace: https://commons.erau.edu/ ijaaa/vol8/iss $2 / 5$ 
Until recently, two low-cost airlines, Ryanair and Southwest, traditionally employed vastly different approaches to customer service and marketing strategies. Prior to 2014, Ryanair focused on low fares and correspondingly low levels of customer service (Thompson, 2012). Ryanair ensured their customers knew not to expect a high level of customer services keeping expectations low (Smith, 2013). These customers knew they would not be treated as well, but valued price over service (Magrath, 2014; Ozcelik \& Findikli, 2014). Using this low price - low service strategy, Ryanair went from 5,000 passengers in 1984 to over 81 million in 2014 (Blake-Tran et al., 2015). Conversely, Southwest also focused on low fares but emphasized higher levels of customer service through their marketing efforts. In response to this marketing strategy and a high level of pride expressed through their advertising focus on customer service, Southwest customers expected to be treated well by the airline (Webb-Morgan, 2017). Until 2020 (Coronavirus pandemic), Southwest turned a profit for 47 straight years; the only U.S. airline to do so (Czaplewski, Ferguson \& Milliman, 2001; Hoopfer, 2020; Schleckser, 2018).

In 2014, Ryanair implemented a new customer service initiative called "Always Getting Better." This was a multi-year plan to improve the customer experience including new cabin interiors, increased leg room, allowance of a second unchecked bag and better food service (Ryanair, 2018). Customers who previously had low expectations of customer service were treated better by the airline. This research focuses on how Ryanair compared to Southwest in perceived customer service, how the perceptions of both airlines have changed since Ryanair instituted its "Always getting better" program in 2014 and how profitability may have been impacted.

\section{Research Question}

The research question was shaped by a previous study: A tale of two airlines: A comparative case study of high-road versus low-road strategies in customer service and reputation management (2019) where survey data from Ryanair and Southwest were compared from 2012-13 passengers. Study recommendations included:

A natural recommendation resulting from this study would be for Ryanair to consider implementing a revised customer service program. It should be noted that Ryanair initiated such a program 2014. Future research will compare Ryanair customer comments during the periods of 2012-2013 and 2015-2018 to determine if these efforts improved customer perception of their airline and if/how that, in turn, affected perceived brand personality and profitability. (Roberts \& Griffith, 2019)

Following this line of thinking, research questions examined in the study are: Is there any difference between how Southwest (high customer expectations) and Ryan Air (formally low customer expectations) are evaluated by customers? 
How did these perceptions change over time after Ryanair focused on customer service?

\section{Purpose}

The purpose of this case study research was to understand the phenomenon of airline customer expectations and perceived customer satisfaction between two low-cost airlines informed by the Expectation Confirmation Theory. Expectation Confirmation Theory would suggest that Ryanair would be judged less harshly by passengers due to low expectations of customer service where Southwest would be judged more harshly by passengers due to a higher expectation of customer service (Oliver, 1980; Spreng et al. 1996). This study extends research by Roberts and Griffith (2019) and includes more recent customer survey data from 2016-2017. It fills an important gap in aviation customer service literature by building on the comparison of two low-cost airlines who have traditionally had diametrically opposed approaches to customer service and incorporating Ryanair's adjusted approach to emphasize customer service (using Southwest as a model). This research examined data on Ryanar prior to and after their enhanced customer service program implementation. Findings will provide insights and a better understanding about how airline marketing models can be used to manage customer expectations in order to provide greater customer satisfaction and potentially realize greater profits.

\section{Literature Review}

Southwest Airlines pre 2014 - "The Somebody Else Up There Who Loves You." Southwest Airlines after 2014 - "Low fares, nothing to hide. That's Transfarency!" Ryanair pre 2014 Director of Customer Service - "We're the airline everyone loves to hate."

Ryanair- post 2014 - Always getting better: "We will not change our low fareswhich we promise will not be beaten ...enjoy a fantastic onboard experience..."

They became the very definitions of their respective brand personalities Southwest is the airline that loves its customers, and Ryanair has been, in the words of director of customer service, Caroline Green, "the airline everyone loves to hate." Part of Michael O'Leary's long-standing marketing strategy has been the philosophy that there is no such thing as bad publicity. Over the years, Ryanair has had plenty of that, and O'Leary seems to have reveled in it, refuting critics with statistics of ever-increasing profit margins and passenger numbers. O'Leary thumbed his proverbial nose at customer satisfaction indices and consumer complaints. However, in 2013, amid unprecedented two consecutive profit warnings, O'Leary announced the implementation of a new, enlightened customer service philosophy.

\section{The Way They Were}


A previous paper (Roberts \& Griffith, 2019) examined the contrasts between the philosophies and business practices of Ryanair and Southwest. Prior to Ryanair's radical shift in philosophy, in contrast to the oft-cited relationship between customer satisfaction and commercial business success, Ryanair consistently presented an antagonistic attitude toward customers but still enjoyed unprecedented success, while Southwest Airlines lagged behind despite their consistent customer focus.

This paper examined the performance of each of these airlines after Ryanair's new policy. Did it make a difference - in either customer satisfaction or company performance? Regarding Southwest, have they continued to keep their customers happy? And in the end, what has been the effect on each airline's bottom line?

\section{Customer Service Expectations and Business Success}

Expectation Confirmation Theory is applicable to the satisfaction a customer experiences after a purchase. If expectations are low, but performance exceeds expectations, customers would tend to be happier. However, if expectations are high but performance does not meet those high expectations, the experience is viewed in a negative way. According to Oliver (1977), both of these situations would result in the disconfirmation of their expectations, rather than the actual level of performance, strongly influencing the customer experience and satisfaction level. Fripp further elaborated on this idea with the Disconfirmation Model of Customer Satisfaction below. 
Figure 1

Disconfirmation Model of Customer Satisfaction 2021

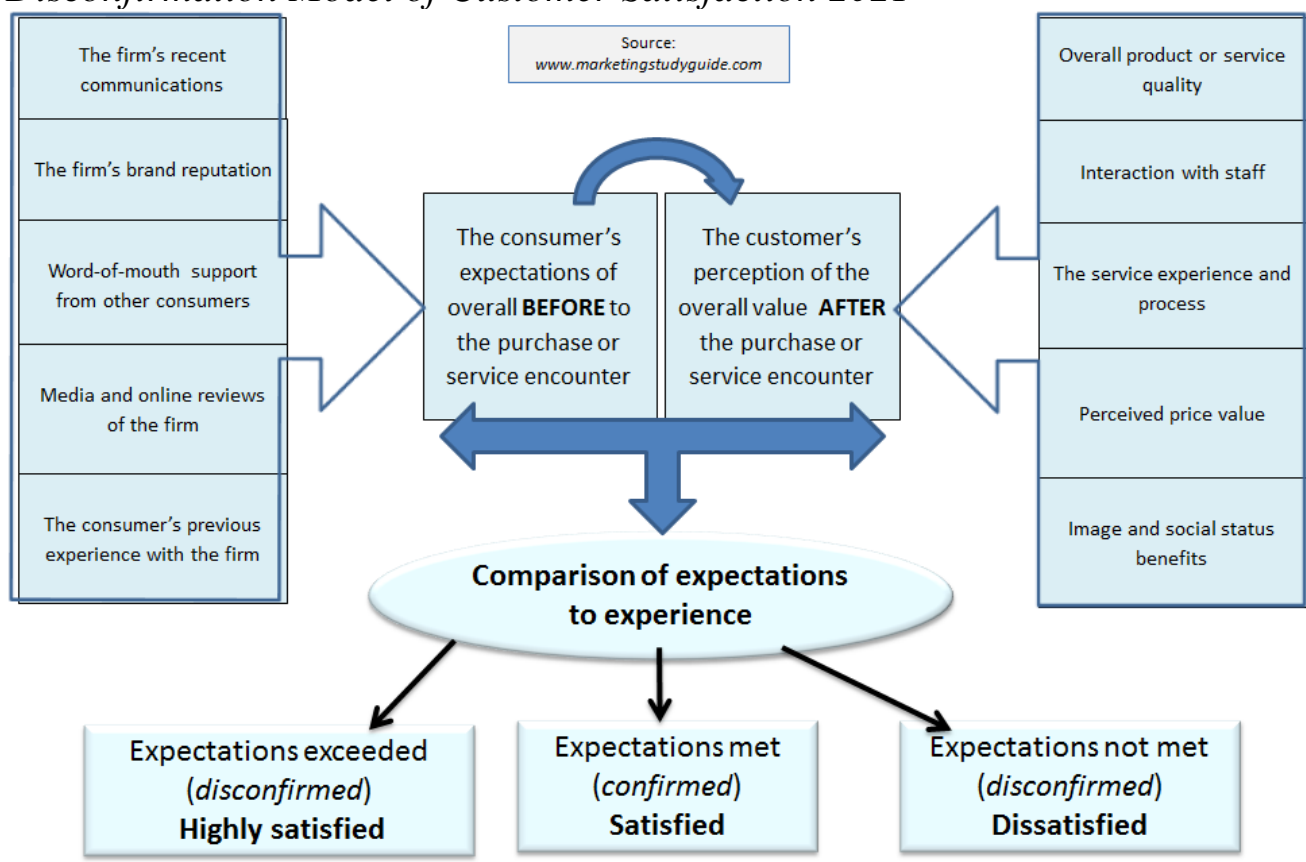

Note. Taken from Fripp (2021). What is the difference between customer satisfaction and customer value? Marketing Study Guide (p. 18). https://www.marketingstudyguide.com/author/ geoff-fripp/page/18/. Company inputs are in the boxes to the left which help shape customer expectations prior to the encounter. Customer impressions after the encounter are illustrated in the boxes on the right side. After the experience customers typically have one of three general feelings about the encounter illustrated in the bottom three boxes.

A key element to consider is that customer expectations are not necessarily uniform or objective. For example, if a customer expects a $\$ 10$ dollar discount on an item and they receive a $\$ 15$ dollar discount, they are very happy. However, if a customer expects a $\$ 50$ dollar discount and only receive a $\$ 35$ dollar price cut, they are unhappy. Customers have different perceptions based on their expectations (Fripp, 2021). Viewed in this light, a similar situation applied to Ryanair and Southwest Airlines.

\section{Customer Expectations and Satisfaction: Ryanair}

Ryanair customers expected and received low fares and their reduced expectations of customer service allowed many to overlook shortcomings in that area. These reduced expectations regarding customer service permeated the organization all the way up to the CEO, Michael O'Leary (Michaels, 2000). O'Leary's quotes on customer service included (Daily Telegraph, 2012, p. 1):

On low fares: "If you can't find a low fare on Ryanair, you're a moron." 
On customer service: "People say the customer is always right, but you know what? They're not. Sometimes they are wrong and they need to be told so."

On apologies: "Are we going to say sorry for our lack of customer service? Absolutely not."

On passengers who forget to print their boarding pass: "We think they should pay 60 Euros for being so stupid."

On refunds: "You're not getting a refund, so $* * * *$ off. We don't want to hear your sob stories. What part of 'no refund' don't you understand?"

\section{Customer Expectations and Satisfaction: Southwest}

Southwest Airlines' approach was similar with respect to low fares but opposite in customer service. As the company communicated pride in good customer service, Southwest passengers expected it. Again, the spirit of legendary CEO Herb Kelleher, was embodied in the corporate culture even after he was gone (Southwest, 2018). The "Mission of Southwest Airlines dedication to the highest quality of Customer Service delivered with a sense of warmth, friendliness, individual pride, and Company Spirit" (Southwest, 2018, p. 1). In the Temkin Experience Ratings annual survey of 10,000 consumers, Southwest has earned the highest score for an airline every year since the ratings began in 2011 (Gould, 2018). Southwest Airlines was ranked 10th in the 2012 Wall Street Customer Service Hall of Fame. Likewise, Southwest typically has a high Fortune's annual ranking of World's Most Admired Companies (usually the only commercial airline in the top 10) (PR Newswire, 2018). Herb Kelleher's quotes on customer service included (Brown, 2016, p. 1):

"A company is stronger if it is bound by love rather than by fear."

"You don't hire for skills, you hire for attitude. You can always teach skills."

"The essential difference in service is not machines or 'things.' The essential difference is minds, hearts, spirits, and souls."

"When someone comes to me with a cost saving idea, I don't immediately jump up and say yes. I ask: what's the effect on the customer?"

Therefore, in similar situations a breach in customer service experienced by a Ryanair passenger would not meet the same reaction of disappointment as a similar problem with Southwest, based on the differing baseline expectations. The 
main variable explaining the different subjective experiences in both cases was the expectations of the customer prior to the encounter - expectations that are intentionally managed by the companies who decide what level of anticipated service to set through their corporate culture, advertising and communications.

In the original study by Roberts and Griffith (2019), Ryanair scored lower on customer service rankings and open area comments bore out the reasons why. These findings will be described in detail in the results portion of the study. It is no secret that Ryanair wanted to be the "Southwest Airlines" of Europe (Menza, 2013). O'Leary referred to the iconic Southwest CEO as, "An absolute ... genius. Kelleher was the one who brought air travel within the pockets of average people" (The Courier-Journal, 2000, p. 1). Initially Ryanair studied Southwest's business operations while neglecting the customer service aspect airlines typically provided.

Ryanair's strategy of low cost and low expectations of customer service seemed to be working with a confident O'Leary stating: "Business books are bulls**t and are usually written by wankers" (Economist, 2007, para 1). In 2012 Ryanair had more than double the daily flights of Southwest. Ryanair carried 134 million passengers as compared to 80 million for Southwest. Additionally, Ryanair's profits dwarfed Southwest US \$679 million to US \$421 million (McClure, 2013). However, the situation changed in 2013.

\section{Ryanair's Pivot to Customer Service}

Ryanair performance in a Which? Magazine (2013) survey ranked the airline as having "the worst customer service out of Britain's 100 biggest brands." While Ryanair could have expected these types of results regarding customer service, the airline's financial and competitive losses in the marketplace were a surprising $£ 28.7$ million loss in the final quarter of 2013.

After years of an approach that insisted "cheap is enough" and that price was the only service that mattered, Ryanair made a decision to implement a new customer service initiative that promised, in O'Leary's classic manner, "would try to eliminate things that unnecessarily $\mathrm{p}^{* * *}$ people off" (Smyth, 2013). The move gained a lot of press attention and speculation. David Williams reporting for Financial Times, asked the questions, "So why did the company's normally uncompromising and abrasive chief executive Michael O'Leary suddenly announce a kinder Ryanair?", "What has happened to the man who urged staff to steal pens from hotels to keep down costs?" and "Why did brusque, "in your face" Mick turn into the luvvie-duvvie, soft, cuddly and caring Michael last week?" His simple conclusion was that Ryanair, and Michael O'Leary, were "worried about the numbers" (McWilliams, 2013).

In response to shareholders' criticisms, O'Leary replied, “I am very happy to take the blame or responsibility if we have a macho or abrupt culture. Some of that may well be my own character deformities" (Salmon, 2013). Specifically, as part of the new approach, he outlined that the airline was considering changes to its 
distribution policy, improving its website, developing its digital marketing strategy, enhancing its image with respect to customer complaints and broadening its appeal to business travelers (CAPA, 2013). The result was the "Always Getting Better" campaign launched in 2014.

By November of 2014, Ryanair reported that they made a net profit of $€ 795$ in the first six months of the year representing a $32 \%$ increase. Traffic grew $4 \%$ to 51.3 million. O'Leary credited this improvement to the implementation of the "Always Getting Better" strategy for ".... improving our customer experience which has delivered higher load factors and yields" (Hosford, 2014). This trend of improved profits has continued ranging from 1,559 million Euros in 2015-2016 to 649 million Euros in 2019-20. The decreased profit in later years (still higher than 2013) was credited to greater payroll costs and higher oil prices (Mazareanu, 2020).

This shift by Ryanair is more in line with customer service models supporting the idea that the "Customer is always right" and that good customer service was imperative to a company's bottom line (Anderson et al., 1994, Luo \& Homburg, 2007; Yeung et al., 2002). Several researchers have confirmed positive correlations between customer service and desire to purchase (Theodorakis et al., 2013). Additional research supported the idea of correlations between customer service and loyalty to a company when making purchase decisions (Kumar, Batista $\&$ Maull, 2011). The question this study attempted to answer was if Ryanair's pivot to customer service was noticed by its passengers and how that changed Ryanair's relative ratings when compared to Southwest.

\section{Hypotheses}

$\mathrm{Ha}_{1}$. Customer survey rating for "Overall Ranking” in 2012-2013 for Ryanair and Southwest will be significantly different than for 2016-2017 ratings.

$\mathrm{Ha}_{2}$. Customer survey ratings for Seat Comfort, Cabin Service, Food Value and if they would recommend the airline in 2012-2013 for Southwest and Ryanair will be significantly different than for 2016-2017 ratings for the same questions.

$\mathrm{Ha}_{3}$. Each airline will experience significantly different customer ratings in 20122013 than the 2016-2017.

\section{Design}

This study builds upon previous work by Roberts and Griffith (2019) which examined customer perceptions of Ryanair and Southwest Airlines using 20122013 data. Ryanair had embarked on a program to enhance customer service between 2013 and the data collection period of this study (2016-2017). The same survey instrument for the previous study's data collection was used in this research. Additionally, a similar comparative case study approach was used to explain the 
"how" and "why" possible behavior/perception changes occurred (Druckman, 2005; Yin, 2014).

\section{Limitations}

1. Participants self-selected themselves to take the survey. This research did not use random assignment nor provided any remuneration for customers who took the survey or penalties for customers who did not. The analysis was retrospective meaning researchers had no contact with, or any way to identify customers who filled out the survey. Although results of this study have merit, the authors do not recommend generalization of results beyond the group of survey respondents.

2. Ryanair operates in the European and Mediterranean regions. Southwest primarily operates in the United States. Both areas of the world have different cultures, air traffic volume and other variables that were not controlled for in this study.

\section{Method}

The study used a descriptive research (survey research) model to compare customer perceptions of Ryanair and Southwest (Gay et al., 2009). The research used information from the Skytrax survey which has been used in the airline industry to rate customer service since 1989. Skytrax states that they are "Dedicated to improving quality of the customer experience for airlines and airports across the world" (Skytrax, 2017a, para. 1).

\section{Participants}

The participants in this study voluntarily filled out a Skytrax online survey to provide perceptions of customer service. The authors focused on results from Ryanair and Southwest based on the specific scope of this study. Ryanair participants commented on routes flown within the European and Mediterranean regions. Participants who rated Southwest airlines were U.S. travelers. Participants were not given any remuneration for participation in the survey. Researchers included data during the same time period (a complete year) for both airlines to preclude seasonal differences from being a moderating variable.

\section{Survey Instrument}

The customer survey used in this study asked customers five Likert scale questions, one multiple choice and one open-ended question on their perception of the airline used for travel. Researchers focused on data from Ryanair and Southwest. Customers were asked to provide and overall ranking (1-poor to 10outstanding). Additionally, customers were asked to rate $(1-$ poor to 5outstanding) for cabin service, food, seat comfort, and value. Customers were asked if they would recommend the airline and had an affirmative (green check) or a negative (red x) option from which to choose. The final question was an open-ended comment area (Skytrax 2017b; Skytrax 2017c; Skytrax; 2020a; Skytrax, 2020b).

\section{Data Examined}


The survey responses examined were from the Skytrax database for both Ryanair (2017b) and Southwest (2017c) for the first data collection period of Jan 2012 to December 2013. Additionally, Skytrax data were examined for both Ryanair and Southwest for the second data collection period of August 2016 to August 2017 (Skytrax 2020a; Skytrax 2020b). The 2012-13 timeframe was chosen because of the different approaches used by Ryanair (increased emphasis on customer service since the first data collection period) and Southwest (high level of customer service - high expectation of service). The second data analysis time period of 2016-17 was chosen because it followed implementation of a customer service program by Ryanair. Both airlines are low-cost airlines.

\section{Treatment of the Data}

Survey data were examined in three ways. First, ordinal responses from customers' survey results were used. These data were compared for the two independent groups (Ryanair customers $n=341$ and Southwest Airlines customers $\mathrm{n}=253$ ). Customers provided "overall ratings" from 1 (poor) to 10 (outstanding). Four questions that followed rated airlines (on a one through five scale) in the areas of seat comfort, cabin service, food and value. The first step replicated the previous study by Roberts and Griffith (2019) as a way to determine differences in consumer perceptions of Ryanair and Southwest. This involved an examination of the 201617 survey results to determine how the two airlines compared with each other on the five survey questions. A second phase of this research compared customer perceptions for each airline individually to determine if there was a change in customer perception over time. The data were divided into two collection periods; 2012-13 and 2016-17 to determine if there were any perceived changes to the level of customer service on the aforementioned five questions in the survey. The MannWhitney $U$ statistic at $\alpha=.05$ was used to evaluate these data and test the first and second hypotheses in the study.

The researchers also examined survey responses on whether Ryanair or Southwest customers would recommend the airline they had flown. Again, the 2019 Roberts and Griffith study was replicated for the second period of data collection (2016-17) to determine how survey responses Ryanair and Southwest compared with each other. The researchers then compared data from the first data period 2012-13 with the second data period of 2016-17 to determine if customer perceptions had changed for each airline during the 3-year gap. These nominal data were tested using Chi Square $\alpha=.05$ to test the third hypothesis in this research (Gay et al., 2009). Statistical results indicated how survey respondents of the two different airlines felt about the service they received. After examining the quantitative data, we also investigated qualitative date provided in open area comments to see why people held their perceptions.

The third phase of data examination focused on open ended responses customers wrote at the end of the survey. Researchers used NVivo software to 
examine a total of 457 customer comments. There were 279 customer comments about Ryanair and 178 comments on Southwest Airlines. Ryanair and Southwest comments were initially reviewed separately. Researchers read and coded each response to allow trends to emerge. Once comments from both airlines were coded, researchers identified common categories between Ryanair and Southwest Airlines which could be directly compared (Gay et al. 2009).

\section{Statistical Results}

Statistical tests shown in the next three tables were used to evaluate the hypotheses in this study. Table 1 shows the analysis for the "Overall Ranking" customers gave to either Ryanair or Southwest Airlines.

\section{Table 1}

Overall Airline Rankings

\begin{tabular}{lcccc}
\hline 2012-2013 Ratings & & & & \\
\hline & Median Rank 1-10 & Mean Rank & Value & p-value \\
\hline Ryanair $(\mathrm{n}=126)$ & 8 & 6.15 & & \\
Southwest $(\mathrm{n}=132)$ & 9 & 7.19 & 14985 & $.0228^{*}$ \\
\hline
\end{tabular}

2016-17 Ratings

\begin{tabular}{lcccc}
\hline & Median Rank 1-10 & Mean Rank & Value & p-value \\
\hline Ryanair $(\mathrm{n}=178)$ & 6 & 5.4 & & \\
Southwest $(\mathrm{n}=104)$ & 3 & 5.1 & 25235 & .9418 \\
\hline
\end{tabular}

Note. Statistically significant results followed by an asterisk*. Data taken from Skytrax survey on Ryanair, (2020a; (2017b) and Southwest (2020b; 2017c) survey for inclusive dates of Jan 2012-Dec 2013 and Aug 2016-Aug 2017. Evaluated with Mann-Whitney U $\alpha=.05$ using Pearson StatCrunch software (2020).

In 2013-13 survey responses indicated that Southwest Airlines had a higher median rank than Ryanair with regard to overall airline ranking and that difference was statistically significant (Roberts \& Griffith, 2019). However, survey takers in 2016-17 for Ryanair and Southwest provided similar ratings for each airline. Although the median rank for Southwest was 3, and Ryanair was 6, the similar mean rankings illustrate that two airlines were not too far apart in 2016-17 resulting in a non-significant finding.

Table 2 shows the results from four separate questions survey respondents answered. Each question evaluated a separate category of seat comfort, cabin/staff service, food and value. 
Table 2

Seat Comfort, Cabin/Staff Service, Food and Value (1-5 stars)

\begin{tabular}{|c|c|c|c|c|c|}
\hline \multicolumn{6}{|l|}{ 2012-13 Ratings } \\
\hline & Airline & $\begin{array}{l}\text { Median } \\
\text { Rank }\end{array}$ & $\begin{array}{l}\text { Mean } \\
\text { Rank }\end{array}$ & Value & p-value \\
\hline \multirow[t]{2}{*}{ Seat Comfort } & Ryanair $(n=160)$ & 3 & 2.919 & & \\
\hline & $\begin{array}{l}\text { Southwest } \\
(n=143)\end{array}$ & 4 & 3.559 & 21072 & $<0.0001^{*}$ \\
\hline \multirow{2}{*}{$\begin{array}{l}\text { Cabin/Staff } \\
\text { Service }\end{array}$} & Ryanair $(n=160)$ & 3 & 2.9 & & \\
\hline & $\begin{array}{l}\text { Southwest } \\
(n=145)\end{array}$ & 4 & 3.834 & 20660 & $<0.0001^{*}$ \\
\hline \multirow[t]{2}{*}{ Food } & Ryanair $(n=108)$ & 3 & 2.556 & & \\
\hline & $\begin{array}{l}\text { Southwest } \\
(n=124)\end{array}$ & 4 & 3.395 & 10228.5 & $<0.0001 *$ \\
\hline \multirow[t]{2}{*}{ Value } & Ryanair $(n=160)$ & 3 & 3.175 & & \\
\hline & $\begin{array}{l}\text { Southwest } \\
(n=146)\end{array}$ & 4.5 & 3.808 & 21924 & $0.0004 *$ \\
\hline
\end{tabular}

2016-17 Ratings

\begin{tabular}{|c|c|c|c|c|c|}
\hline & Airline & $\begin{array}{l}\text { Median } \\
\text { Rank }\end{array}$ & $\begin{array}{l}\text { Mean } \\
\text { Rank }\end{array}$ & Value & p-value \\
\hline \multirow[t]{2}{*}{ Seat Comfort } & Ryanair (n=176) & 3 & 2.551 & & \\
\hline & $\begin{array}{l}\text { Southwest } \\
(\mathrm{n}=102)\end{array}$ & 3 & 2.873 & 23272.5 & $0.0418 *$ \\
\hline \multirow{2}{*}{$\begin{array}{l}\text { Cabin/Staff } \\
\text { Service }\end{array}$} & Ryanair $(n=176)$ & 3 & 3.159 & & \\
\hline & $\begin{array}{l}\text { Southwest } \\
(n=102)\end{array}$ & 4 & 3.471 & 23427 & 0.0733 \\
\hline \multirow[t]{2}{*}{ Food } & Ryanair $(n=94)$ & 2.5 & 2.468 & & \\
\hline & Southwest $(n=85)$ & 3 & 2.976 & 7667 & $0.0189 *$ \\
\hline \multirow[t]{2}{*}{ Value } & Ryanair $(n=178)$ & 4 & 3.320 & & \\
\hline & $\begin{array}{l}\text { Southwest } \\
(n=104)\end{array}$ & 3 & 3.038 & 26002 & 0.2024 \\
\hline
\end{tabular}

Note. Statistically significant results followed by an asterisk*. Data taken from Skytrax survey on Ryanair, (2020a; (2017b) and Southwest (2020b; 2017c) survey for inclusive dates of Jan 2012-Dec 2013 and Aug 2016-Aug 2017. Evaluated with Mann-Whitney U $\alpha=.05$ using Pearson StatCrunch software (2020).

As shown in Table 2, 2012-13 survey respondents rated Southwest Airlines significantly higher than Ryanair for seat comfort and food. The same held true for 
2016-17 survey takers. In both cases, the differences were statistically significant. The biggest changes occurred when comparing responses between the airlines on cabin/staff service and value. In 2012-13, survey respondents rated Southwest significantly higher in both cabin/staff services and overall value. Survey respondent ratings in 2016-17 yielded a non-significant difference between Southwest and Ryanair for cabin/staff service. Additionally, Ryanair was rated slightly higher for overall value than Southwest although this difference was not statistically significant. These lower ratings by Southwest 2016-17 survey respondents support the conclusion that Southwest's advantage decreased in the two areas of cabin/staff services and overall value when compared to Ryanair

The survey question asked "Would you recommend this airline?" Results follow in Table 3.

Table 3

Results for "Would you recommend this airline?"

\begin{tabular}{|c|c|c|c|c|c|}
\hline \multicolumn{6}{|c|}{ 2012-2013 Ratings } \\
\hline & Yes & No & Total & Value & Chi Square \\
\hline Ryanair & $70(42.7)$ & $94(57.3 \%)$ & $164(100 \%)$ & & \\
\hline Southwest & $93(62.4 \%)$ & $56(37.6 \%)$ & $149(100 \%)$ & & \\
\hline Totals & $163(52.1 \%)$ & $\begin{array}{l}150 \\
(47.9 \%)\end{array}$ & $313(100 \%)$ & 12.181 & $0.0005^{*}$ \\
\hline \multicolumn{6}{|c|}{ 2016-2017 Ratings } \\
\hline & Yes & No & Total & Value & $\begin{array}{l}\text { Chi } \\
\text { Square }\end{array}$ \\
\hline Ryanair & $102(57.6 \%)$ & $75(43.4 \%)$ & $177(100 \%)$ & & \\
\hline Southwest & $45(43.3 \%)$ & $59(56.7 \%)$ & $104(100 \%)$ & & \\
\hline Totals & $147(52.3 \%)$ & $\begin{array}{l}134 \\
(47.7 \%)\end{array}$ & $281(100 \%)$ & 5.413 & $0.02 *$ \\
\hline
\end{tabular}

Note. Data taken from Skytrack survey on Ryanair, (2020a; (2017b) and Southwest (2020b; 2017c) survey for inclusive dates of Jan 2012-Dec 2013 and Aug 2016-Aug 2017. Analyzed with Chi Square contingency table, $\alpha=.05$ at 1 degree of freedom using Pearson StatCrunch software (2020).

As noted in the previous study by Roberts and Griffith (2019) 2012-13 survey takers rated Southwest Airlines significantly different (higher) than Ryanair on the question "would you recommend this airline?" Slightly more than $62 \%$ of Southwest customers indicated they would recommend Southwest. Only $43 \%$ of Ryanair customers would recommend using Ryanair. These ratings switched somewhat when examining data from 2016-17. Just under 58\% of survey respondents indicated they would recommend Ryanair compared to just over $43 \%$ who indicated they would recommend Southwest. These results were further 
illustrated when specifically examining how ratings changed within each airline from the 2012-13 results to the 2016-17 survey responses.

\section{Changes in Ratings for Each Airline Between 2012-2013 and 2016-17}

The second phase of the study determined whether the rankings for each airline changed between the data collection periods of 2012-13 and 1016-17. The results of these comparisons are shown in Table 4.

\section{Table 4}

Changes in Ratings for Each Airline between 2012-13 and 2016-17

\begin{tabular}{l|lc|lc}
\hline & \multicolumn{2}{|c|}{ Ryanair } & \multicolumn{2}{c}{ Southwest } \\
\hline \multirow{3}{*}{ Overall Ranking } & Change & Significant? & Change & Significant? \\
\cline { 2 - 5 } Seat Comfort & Decreased & Yes & Decreased & Yes \\
Cabin/Staff Service & Increased & Yes & Decreased & Yes \\
Food & No- & & No- & \\
Value & Decreased & & Decreased & \\
Recommend & Increased & & Decreased & Yes \\
\hline
\end{tabular}

Changes in "Overall Rank" for both Ryanair and Southwest were statistically significant between survey years. Ryanair's median rank dropped from the 2012-13 rating of 8 to the 2016-17 rating of $6(U=20999, p=0.0167)$. Southwest's median rank dropped from 9 as measured in 2012-13 to the 2016-17 rating of $3(\mathrm{U}=17701, \mathrm{p}<0.0001)$. Survey respondent rankings dropped significantly for both Ryanair and Southwest between the two data collection periods of 2012-13 and 2016-17.

Changes in "Seat Comfort" ratings from 2012-13 to 2016-17 in both Ryanair and Southwest were significant when compared using the Mann-Whitney U statistic. Ryanair had a median rank of 3 for both data periods but showed a decrease in the mean rank $(U=29268, p=0.0077)$. Southwest's ratings dropped a full median rank from 4 in 2012-13 to 3 in 2016-17 and in the mean rank from 3.559 to $2.873(\mathrm{U}=19751.5 \mathrm{p}<0.0001)$. These data offer support to the research hypothesis that the ratings would change for both airlines between the two data collection periods

Changes in "Cabin Service" were not statistically significant for Ryanair in 2012-2013 (median = 3) and 2016-17 (median = 3), $(\mathrm{U}=25639, \mathrm{p}=0.1284$ ). Southwest's median ranking of 4 for both data collection periods was not statistically significant, $(\mathrm{U}=18807 \mathrm{p}=0.1158)$.

Changes in "Food" ratings between the two data collection periods of 201213 (median $=3$ ) and 2016-17 (median $=2.5)$ were not statistically significant for Ryanair (U=11159, $\mathrm{p}=0.6233)$. Southwest's "Food" rating dropped from a median 
of 4 in 2012-13 to 3 in 2016-17, ( $U=13821.5 \mathrm{p}=0.055)$ but this change was not enough evidence to support rejection of the idea that ratings would change between the two data collection periods for "Food." As noted in the discussion about Table 3 earlier, Southwest was still rated higher for "food" than Ryanair and this difference stayed relatively constant between the two rating periods.

Changes in the "Value" rating for the individual airlines were mixed with a non-significant change for Ryanair which increased from a median of 3 in 201617 to a median of 4 in 2016-17, $(\mathrm{U}=26372.5 \mathrm{p}=0.3908)$. The data showed a statistically significant change for Southwest which dropped a full median rank from 4.5 in 2012-13 to 3 in 2016-17, ( $U=20183.5 \mathrm{p}=0.005)$. These findings partially supported the idea that survey ratings for "value" would change between the data collection periods.

The comparison between survey periods of 2012-13 and 2016-17 showed that significantly more passengers surveyed recommended Ryan Air in the 201617 timeframe $(57.6 \%)$ than in 2012-13 (42.7\%). This difference was statistically significant $X^{2}(1,341)=7.605, p=0.0058$. A decrease of Southwest Airlines passengers from 2016-17 (43.3\%) stated they would recommend the airline compared to $62.4 \%$ who stated they would recommend the airline from the 201213 data collection period. This difference was statistically significant $X^{2}(1,253)=$ 9.056, $\mathrm{p}=0.0026$.

\section{Quantitative Summary}

Survey responses between the two collection periods of 2012-13 and 201617 exhibited different results in several areas between the airlines. Southwest was clearly a higher rated airline than Ryanair for 2012-13 survey takers who rated Southwest higher in overall rating, seat comfort, cabin staff service, food and value. Additionally, a significantly higher percentage of Southwest customers recommended Southwest (62.4\%) comparted to only $42.7 \%$ of Ryanair passengers who responded that they would recommend Ryanair.

Survey respondents in 2016-17 expressed different views. Southwest was rated significantly higher by their customers who answered the survey for seat comfort and food than ratings provided by Ryanair customers. However, the differences between the two airlines were not statistically significant for "Overall Rating", "cabin/staff service" or "value." A notable statistically significant difference between the two airlines was the question about recommending the airline. Percentages were almost flipped from the 2012-13 responses compared to the data provided by 2016-17 survey respondents where most Ryanair respondents $(57.6 \%)$ would recommend the airline compared to only $43.3 \%$ for Southwest.

The second phase of the analysis attempted to determine if responses for each airline changed between the 2012-13 and 2016-17 data collection periods. Ryanair survey responses were significantly different between 2012-13 and 201617 for "Overall Rating," "Seat Comfort" and if they would recommend Ryanair. 
Ryanair's "Overall Rating" decreased, but "Seat Comfort" and "Recommendation" significantly increased. Non-statistically significant changes for Ryanair included "Cabin Service," (remained roughly the same) "Food" (decreased slightly) and "Value" (increased).

Southwest ratings also changed between the two data collection periods of 2012-13 and 2016-17. Ratings for "Overall Rank," "Seat Comfort," "Value" and if survey respondents would recommend Southwest all decreased to statistically significant degrees. Non-statistically significant survey responses were relatively stable for "Cabin Service" and decreased for "Food."

\section{Recurring Themes from Open Area Comments}

The quantitative data from 2016-17 explained what survey respondents felt, but further analysis was conducted to determine the reasons why. Survey responses were analyzed using NVivo software to identify significant themes or sub themes from open area comments on the Skytrax surveys. Ryanair $(n=279)$ and Southwest Airlines $(n=178)$ customer responses were examined for significant trends. Some responses involved several different comments on multiple themes and/or several areas within the same major theme. Customer survey comments, themes, and subthemes shown in Table 5 below.

\section{Table 5}

Overview of Ryanair and Southwest Airline Customer Themes Ranked by Percentage of Comments (2016-217 Survey)

\begin{tabular}{|c|c|c|c|}
\hline \multicolumn{2}{|l|}{ Ryanair } & \multicolumn{2}{|c|}{ Southwest Airlines } \\
\hline Theme & No. & Theme & No. \\
\hline $\begin{array}{l}\text { Customer Service - } \\
\text { Good }\end{array}$ & $81(29 \%)$ & $\begin{array}{l}\text { Inefficient or } \\
\text { Unwelcome Processes }\end{array}$ & $57(32 \%)$ \\
\hline $\begin{array}{l}\text { Inefficient or } \\
\text { unwelcome Processes }\end{array}$ & $56(20 \%)$ & $\begin{array}{l}\text { Customer Service - } \\
\text { Good }\end{array}$ & $47(26 \%)$ \\
\hline Efficient & $37(13 \%)$ & Value & $37(21 \%)$ \\
\hline Value & $31(11 \%)$ & $\begin{array}{l}\text { Discourteous or } \\
\text { unfriendly service }\end{array}$ & $14(8 \%)$ \\
\hline $\begin{array}{l}\text { Cabin Configuration } \\
\text { and Cleanliness - Good }\end{array}$ & $29(10 \%)$ & $\begin{array}{l}\text { Cabin Configuration } \\
\text { and Cleanliness - Good }\end{array}$ & $12(7 \%)$ \\
\hline & & Efficient & $8(4 \%)$ \\
\hline $\begin{array}{l}\text { Cabin Configuration } \\
\text { and Cleanliness - Poor }\end{array}$ & $19(7 \%)$ & $\begin{array}{l}\text { Cabin Configuration } \\
\text { and Cleanliness - Poor }\end{array}$ & $2(1 \%)$ \\
\hline $\begin{array}{l}\text { Discourteous or } \\
\text { unfriendly service }\end{array}$ & $18(6 \%)$ & $\begin{array}{l}\text { Paid as much as } \\
\text { traditional airlines }\end{array}$ & $1(1 \%)$ \\
\hline
\end{tabular}




\begin{tabular}{ll|l}
\hline $\begin{array}{l}\text { Supportive of rules and } \\
\text { procedures }\end{array}$ & $6(2 \%)$ & \\
\hline $\begin{array}{l}\text { Paid as much as } \\
\text { traditional airlines }\end{array}$ & $2(1 \%)$ & \\
\hline
\end{tabular}

Note. Data taken from Skytrax survey on Ryanair (2020a) and Southwest (2020b) survey for inclusive dates of Aug 2016-Aug 2017. Data were coded into NVivo software Version 12 (2019). Percentages are expressed in parentheses by the actual number of coded responses indicating number of comments in a specific theme divided by the total number of coded comments for the airline.

\section{Ryanair Themes}

Twenty-nine percent of the comments coded for Ryanair survey responses indicated that the airline delivered high levels of customer service. Within this category, $20 \%$ cited courteous friendly and professional service, $6 \%$ stated the boarding procedures were good, and $1 \%$ of all Ryanair coded responses called their experience with the airline "enjoyable. One survey respondent commented:

Two of my most pleasant flights with Ryanair. It's amazing how much the airline's customer service has improved in recent years, particularly with their allocated seating, extra cabin baggage allowance, use of primary airports and excellent mobile app, features, all of which, have significantly enhanced the overall travel experience. (Skytrax, 2020a)

The second major theme involved inefficient or unwelcome processes $(20 \%)$. The top four issues commented about in this category were check-in and boarding procedures (9\%), expensive food and drink (3\%), flight delays handled poorly $(3 \%)$, charge to print boarding passes $(2 \%)$, emphasis on selling food and other products $(2 \%)$, and delays with baggage $1 \%$. One respondent commented: "I'm currently stood (sic) waiting for boarding in what can only be described as a glorified shed in Budapest Airport. It's $-5 \mathrm{c}$ and there are no seats, on my flight there are pregnant women and families with young children" (Ryanair, 2020a).

Thirteen percent of Ryanair survey respondents commented on the airline's efficiency. One respondent commented: "I had a great on time flight with Ryanair from Paris Beauvais to Venice Treviso for a great price. Everything ran smoothly, the ground and onboard crew were informative and pleasant" (Skytrax, 2020a). Eleven percent indicated Ryanair was a good value. A typical comment was "Brussels to Berlin Schonefeld with Ryanair. This is one of the cheapest airlines I have ever seen. For a 1-hour flight it was so worth the money" (Skytrax, 2020a). Another passenger commented: "Paid 20 euros, which is absolutely unbeatable" (Skytrax, 2020a).

Cabin Configuration was rated "good" by $10 \%$ of Ryanair survey respondents. In this category, Six percent indicated the cabin was clean and $4 \%$ mentioned comfortable seating. Not all survey respondents agreed, however. Seven percent indicated cabin configuration and cleanliness was poor. Comments in this 
area cited uncomfortable seats and leg room (4\%), dirty cabin (3\%) and lack of space for handbags in the cabin $(<1 \%)$.

Six percent indicated they experienced discourteous or unfriendly service. A typical comment in this area was "The staff on the plane are generally unhelpful and unfriendly, the staff on the ground are the same and you can add look disinterested" (Skytrax, 2020). Two percent indicated they were supportive of Ryanair rules and procedures. Less than $1 \%$ of comments mentioned that they paid as much for Ryanair as a traditional (higher cost) airline.

\section{Southwest Airline Themes}

Thirty-two percent of Southwest survey respondents expressed difficulties with inefficient or unwelcome processes. Within this category, $10 \%$ of overall Southwest respondents cited issues of flight delays which were handled poorly, $8 \%$ mentioned poor seating policies, $4 \%$ cited issues with check-in procedures, $3 \%$ mentioned flight cancelation issues, another $2 \%$ commented on flight delays, $2 \%$ had issues with baggage, $2 \%$ had "Rapid Rewards" policy issues and $1 \%$ mentioned connecting flight difficulties. One survey respondent stated: "Southwest Airlines what happened? You used to be the fun Go-To airline that, no matter how bad the others, never lost its sense of humor. Now your staff are as frazzled, checked-out, and nasty as the others!" (Skytrax, 2020b). Another survey respondent stated: 'This particular flight was the worst. We were already delayed and then sat on the tarmac for almost 30 mins. I don't know what happened to Southwest, but please go back to the way it was." (Skytrax, 2020b). Another survey respondent stated:

The worst airline ever. Me and my family flew on it 3 times within last week. All three flights were delayed with two of them delayed by 3 and 4 hours and this is for a $2 \mathrm{hr}$ direct flight. All our plans got messed up. (Skytrax, 2020b)

The second major theme cited by southwest survey respondents was good customer service (26\%). In this category, $19 \%$ overall mentioned courteous friendly and professional service, $4 \%$ indicated their experience with Southwest was enjoyable, and 3\% gave favorable comments to check-in and boarding procedures. A survey respondent stated: "All in all Southwest keeps delivering a good product on this flight and the ground staff and cabin crew do a good job." (Skytrax, 2020b). Another commented: "I have had 99\% good experiences with Southwest Air. I wish they flew to Hawaii and Europe!" (Skytrax, 2020b). Another comment regarding customer service stated:

I was running late for a flight and arrived at the gate. Suddenly a lady comes running over "are you Rebecca?!" I can only nod yes before I bend over to catch my breath, as she barely slows to pull open the door and continues at full speed down the bridge. A flight attendant comes back with her to scan my ticket, and I thankfully board the plane and arrive home at midnight. 
Words cannot express how much I needed to catch that flight and not extend this trip. Thank you Southwest! (Skytrax, 2020b)

The third major theme was value (21\%). Regarding value, $10 \%$ indicated it was inexpensive to fly, $7 \%$ expressed appreciation for no charge for baggage, and $4 \%$ commented on no change fees. A typical comment in this area was: "Over all a good value, quick trip, on time, nice crew, comfortable, clean plane. In short the usual Southwest experience (Skytrax, 2020b).

Cabin configuration and cleanliness was rated positively by $7 \%$ of Southwest respondents. Five percent mentioned comfortable seats and $2 \%$ mentioned clean cabins. Efficiency was cited by $4 \%$ of Southwest passengers who completed the survey. Negative ratings on cabin configuration and cleanliness were made by $1 \%$ of survey respondents who cited worn and or uncomfortable seats and lack of legroom. Another 1\% of survey respondents complained they paid as much for tickets on Southwest (low-cost airline) as for traditional higher cost airlines.

\section{Changes in Areas Commented On for Each Airline}

Specific themes commented on by passengers changed between the two data collection periods of 2012-13 and 2016-17. Perceptions as expressed through open area comments were better in five of seven categories for Ryanair and decreased in four of seven categories for Southwest as shown on table 6 below.

Table 6

Changes Between 2012-13 and 2016-17 in Open Area Comment Ranks Within Each Airline

\begin{tabular}{l|ccc|ccc}
\hline & \multicolumn{5}{|c|}{ Ryanair } & \multicolumn{3}{c}{ Southwest Airlines } \\
\hline Year & $\begin{array}{c}2012- \\
13\end{array}$ & $\begin{array}{c}2016- \\
17\end{array}$ & Change & $\begin{array}{c}2012- \\
13\end{array}$ & $\begin{array}{c}2016- \\
17\end{array}$ & Change \\
\hline $\begin{array}{l}\text { Customer Service }- \\
\text { Good }\end{array}$ & 3 & 1 & +2 & 1 & 2 & -1 \\
\hline Efficient & 4 & 3 & +1 & 3 & 6 & -3 \\
\hline Value & 5 & 4 & +1 & 5 & 3 & +2 \\
\hline $\begin{array}{l}\text { Cabin } \\
\text { Configuration and } \\
\text { Cleanliness - Good }\end{array}$ & 7 & 5 & +2 & 4 & 5 & -1 \\
\hline Negative Trends: & & & & & & \\
\hline $\begin{array}{l}\text { Inefficient or } \\
\begin{array}{l}\text { Unwelcome } \\
\text { Processes }\end{array}\end{array}$ & 2 & 2 & - & 2 & 1 & -1 \\
\hline $\begin{array}{l}\text { Cabin } \\
\text { Configuration and } \\
\text { Cleanliness - Poor }\end{array}$ & 6 & 6 & - & 7 & 7 & - \\
\hline
\end{tabular}




\begin{tabular}{l|lll|lll}
\hline $\begin{array}{l}\text { Discourteous or } \\
\text { Unfriendly Service }\end{array}$ & 1 & 7 & +6 & 6 & 4 & -2 \\
\hline
\end{tabular}

Note. Improvements in perceptions denoted by a positive number in the change columns. These calculations are not mathematical but show improvements in the ranking of comments. The first four rows of data (positive perceptions) were calculated differently than last three rows (themes that focused on negative comments). 2012-13 rankings taken from A Tale of Two Airlines: A Comparative Case Study of High-Road versus Low-Road Strategies in Customer Service and Reputation Management (Roberts \& Griffith, 2019).

As shown in Table 7, ranking of the most popular open area comments changed for both airlines between 2012-13 and 2016-17. Ryanair saw more positive comments in the areas of Customer Service, Efficiency, Value, Cabin Configuration and fewer negative comments regarding Discourteous or Unfriendly Service in the 2016-17 collection period than in the 2012-13 collection period. Two areas held similar rankings of themed comments between 2013-13 and 2016-17 for Ryanair; Inefficient or Unwelcome Processes and poor Cabin Configuration and Cleanliness.

Southwest had different results with negative changes in the ranking of themes in four areas in the 2016-17 data, Customer Service (Good), Efficiency, Cabin Configuration and Cleanliness (Good), Inefficient or Unwelcome Process and Discourteous or Unfriendly Service. The Cabin Configuration and Cleanliness (Poor) area held the same rank in the 2012-2013 and 2016-17 data.

\section{Discussion}

Quantitative and qualitative tools used to examine Ryanair and Southwest illustrated a shift in customer perceptions regarding both airlines. In direct comparisons using 2016-17 data, quantitative results showed no statistical difference in overall ratings between the airlines. In the 2012-13 data collection period, Southwest passengers ranked the airline significantly higher than ratings given by Ryanair passengers to their airline. In the 2012-2013 responses, Southwest's ratings were significantly higher for Seat Comfort, Cabin/Staff Service, Food and Value than Ryanair's customer ratings. The 2016-17 data showed that Southwest was still rated significantly higher in the areas of Seat Comfort and Food. However, the differences in ratings were not statistically significant between the airlines for Cabin/Staff Service and Value. The 2012-13 survey respondents rated Southwest significantly higher for "Would you recommend this airline" than Ryanair survey takers. However, survey takers in 2016-17 rated Ryanair significantly higher than Southwest for the same question. These data indicate a change in perception between the two airlines favoring Ryanair and coincide with Ryanair's new focus on customer service that occurred between the two data collection periods.

These changes were also reflected when ranking themes from most to least cited in open area comments. In 2012-13, comments for Ryanair focused on 
discourteous or unfriendly service, inefficient or unwelcome processes good customer service and efficiency. In 2016-17, Most Ryanair comments focused on good customer service, inefficient or unwelcome processes, efficiency and value. Ryanair improved in five of the seven major themes and remained stable in two.

In 2012-13, the number one theme commented on by Southwest customers was good customer service followed by inefficient or unwelcome processes, efficiency and value. 2016-17 Southwest survey takers focused on inefficient or unwelcome processes, good customer service, efficiency and discourteous or unfriendly service. Perceptions of Southwest improved in one area, and rated lower in five areas staying constant in only one of the seven major themes. Open area perceptions of Ryanair mostly improved while perceptions of Southwest were less positive.

\section{Conclusions}

In this study, it appears the efforts made by Ryanair to improve customer service were noticed by their passengers who responded to the survey. Most differences in perceptions between Ryanair and Southwest have either been eliminated or reversed in favor of Ryanair. A surprising finding between 2012-13 and 2016-17 data collection periods was the switch in favor of Ryanair whose passengers would recommend their airline at a significantly higher rate that Southwest passengers.

When comparing each airline's data over time (2012-13 data vs 2016-17), survey question results indicated that perceptions of Ryanair's customer service have improved in three of seven areas and perceptions of Southwest's customer service has declined in four of seven areas. Airline passenger service perceptions are impacted by customer expectations and sometimes, events beyond the control of an air carrier. However, concerted efforts appear to make a positive difference in the minds of passengers.

\section{Recommendations}

The Coronavirus has had a devastating impact on airlines. Future research should be conducted to determine how effectively air carriers adjusted to the disruption to the airline industry. Specifically, quality customer service has been a core concept for Southwest Airlines ever since its inception. Ryanair has recently adopted a customer service model. A future study along similar lines to this research should be conducted to determine how well these two airlines adjust to new requirements and difficulties presented by the pandemic. Possible data periods to compare are 2016-17 with 2021-22.

Airlines should continue to emphasize customer service using corporate culture and advertising to communicate the level of service customers should expect, understanding that customers' expectations have a prominent role in their overall experience and level of satisfaction. 


\section{References}

Anderson, E.W., Fornell, C. \& Lehmann, D.R. (1994). Customer satisfaction, market share and profitability. Journal of Marketing, 56, 53-66.

Blake-Tran, N., Perkinson, J., Sinnenbert, T., \& Harrision, J. S. (2015). Ryanair holdings. University of Richmond. https://robins.richmond.edu/ documents/Ryanair.pdf

Brown, J. (2016, January 13). 30 intelligent Herb Kelleher quotes. https://addicted2success.com/success-advice/30-intelligent-herb-kelleherquotes/

CAPA Centre for Aviation. (October 3, 2013). Ryanair's new customer-friendly approach. Really? Aviation Week Network. www.centreforaviation.com

Courier-Journal (2000, September 12). Michael O'Leary borrowed cues from Southwest. The Courier-Journal from Louisville, Kentucky, p. 46.

Czaplewski, A., Ferguson, J., \& Milliman, J. (2001). Southwest Airlines: How internal marketing pilots success. Marketing Management, 10(3) 14-17

Daily Telegraph. (2012, September 5). The most wonderfully offensive quotes from Ryanair boss Michael O'Leary. www.telegraph.co.uk

Druckman, D. (2005). Doing research. Sage.

Fripp, G. (2021). What is the difference between customer satisfaction and customer value? Marketing Study Guide (p. 18). https://www.marketingstudyguide.com/author/geoff-fripp/page/18/

Economist. (2007, August 23). Snarling all the way to the bank. www.economist.com

Friedberg, J., \& Friedberg, K. (1997). Nuts! Southwest Airlines' crazy recipe for business and personal success. Broadway Books.

Gay, L. R., Mills, G. E., \& Airasian, P. W. (2009). Educational research: Competencies for analysis and application (9th ed.). Pearson.

Gould, M. (2018, August 23). Ryanair ignores the link between customer experience and employee experience. www.business 2 community.com

Hoopfer, E. (2020). Southwest Airlines CEO discusses 47-year profitability streak. Houston Business Journal. https://www.bizjournals.com/houston/ news/2020/08/15/southwest-47-years-profitable-work-from-home.html

Hosford, P. (2014). Being nicer is making more money for Ryanair. Thejournal.ie. https://www.thejournal.ie/ryanair-half-year-profits-up1759135-Nov2014/

Kumar, V., Batista, L., \& Maull, R. (2011). The impact of operations performance on customer loyalty. Service Science, 3(2), 158-171.

Luo, X., \& Homburg, C. (2007). Neglected outcomes of customer satisfaction. Journal of Marketing, 71(2):133-149.

Magrath, A. (2014, October 31). Ryanair named second-worst brand in the WORLD for customer service. Retrieved from: www.dailymail.co.uk. 
Maxareanu, E. (2020). Ryanair net profit 2011-2020. Statista. https://www.statista.com/statistics/756093/ryanair-net-profit/

McClure, G. (2013, December). Polyester airlines: Ryanair vs. Southwest. Retrieved from: www.flightfox.com

McWilliams, D. (September 27, 2013). The misery of a Ryanair flight is a common tie that binds. Financial Times, www.ft.com

Menza, J. (2013, June 24). We're Europe's Southwest Airlines. CNBC. https://www.cnbc.com/id/100839583

Michaels, D. (2000, September 6). Inspired by U.S.'s no-frills Southwest, Ryanair reshapes European travel. The Wall Street Journal. www.wsj.com

Oliver R. L. (1977). Effect of expectation and disconfirmation on postexposure product evaluations - An alternative interpretation. Journal of Applied Psychology, 62(4), 480.

Oliver R. L. (1980). A cognitive model of the antecedents and consequences of satisfaction decisions. Journal of Marketing Research, 17(4), 460.

Ozcelik, G., Findikli, M. (2014). The relationship between internal branding and organizational citizenship behavior: The mediating role of personorganization fit. https://ac.els-cdn.com/S1877042814051763/1-s2.0S1877042814051763-main.pdf?_tid=4c1d1a80-62e6-4105-b1cc951509b141a6\&acdnat $=1549851202 \_6 d 179 f d e b 32658682 \mathrm{fbee} 3205852 \mathrm{ec}$ e1

PR Newswire. (2018, January 19). Southwest Airlines again among FORTUNE's top 10 world's most admired companies. www.prnewswire.com

Roberts, D., \& Griffith, J. C. (2019). A tale of two airlines: A comparative case study of high-road versus low-road strategies in customer service and reputation management. International Journal of Aviation, Aeronautics, and Aerospace, 6(2). https://doi.org/10.15394/ijaaa.2019.1317

Ryanair. (2018). Always getting better. https://www.ryanair.com/mt/en/usefulinfo/about-ryanair/always-getting-better

Salmon, J. (September 21, 2013). Ryanair's Michael O'Leary vows to stop annoying customers with 'macho' culture. The Daily Mail. www.dailymail.co.uk

Schleckser, J. (2018). Why Southwest has been profitable 45 years in a row. Inc. https://www.inc.com/jim-schleckser/why-southwest-has-been-profitable45-years-in-a-row.html

Skytrax. (2017a). Quality is our journey. http://skytraxresearch.com/

Skytrax. (2017b). Ryanair customer reviews. http://www.airlinequality.com/ airline-reviews/ryanair/

Skytrax. (2017c). Southwest Airline customer reviews. http://www.airlinequality.com/airline-reviews/southwest-airlines/ 
Skytrax. (2020a). Ryanair customer reviews. https://www.airlinequality.com/ airline-reviews/ryanair/

Skytrax. (2020b). Southwest Airline customer reviews. https://www.airlinequality.com/airline-reviews/southwest-airlines/

Smith, O. (2013, September 19). Ryanair 'worst' brand for customer service. www.telegrpah.co.uk

Smyth, J. (September 20, 2013). O'Leary U-turn as he promises a kinder, gentler Ryanair. Financial Times. www.ft.com

Southwest Airlines. (2018). About. https://www.southwest.com/html/aboutsouthwest/index.html

Spreng R. A, MacKenzie, S. B., \& Olshavsky, R. W. (1996). A reexamination of the determinants of consumer satisfaction. Journal of Marketing, 60(3), 15.

Theodorakis, N. D., Alexandris, K., Tsigilis, N., \& Karvounis, S. (2013).

Predicting spectators' behavioral intentions in professional football: The role of satisfaction and service quality. Sport Management Review, 16(1), 85-96.

Thompson, B. (2012, March 26). If the customer experience is so important, how do you explain the success of Ryanair? www.customerthink.com

Webb-Morgan, M. (2017, February 22). Southwest Airlines: A case study in great customer service. Retrieved from: www.business.com

Which? (2013, 19 September). Which? reveals best and worst brands for customer satisfaction. www.which.co.uk.

Yeung, M. C. H., Ging, L. \& Ennew, C. T. (2002). Customer satisfaction and profitability: A reappraisal of the nature of the relationship. Journal of Targeting, Measurement and Analysis for Marketing, 11(1), 24-3.

Yin, R. K. (2014). Case study research: Design and methods (5th ed.). Sage. 